Oleksandr Kovalenko, Candidate of Pedagogical Sciences, Sumy State A. S. Makarenko Pedagogical University, 87, Romenskaya str., Sumy, 40002, Ukraine ORCID: 0000-0003-1043-6679 ResearcherID: AAG-4107-2020/

\title{
CULTUROLOGICAL APPROACH IN MODERN TRAINING OF TOURIST SUPPORT SPECIALISTS
}

This article addresses the issue of defining and applying a culturological approach in the modern training of specialists in tourist support, namely tour and excursion guides. It is determined that the problem of searching for methods, means and forms of improving modern culturological training and retraining of specialists of tourist support (guides) to work with tourists is currently relevant in our country and abroad. In the work it is stated that today, culture is the integral foundation of professional training of specialists, namely values and comprehended knowledge, ideas, which have been reflected in art, religion, traditions and human experience. The article defines culturological approach and conditions and features of its use in professional training of future tourist support specialists. It is also stated that in solving the task of professional development of future specialists of tourist support (guides) on the basis of culturological approach, it is necessary to build professional training as a process of introducing a person into the context of human culture, acquiring the ability to live in compliance with demands of a particular culture by individuals, reproduction of its achievements and creation of new spiritual and tangible assets.

Keywords: tour guide, tourist support specialists, culture, culturological approach, training of specialists.

Relevance of research topic. Every year more and more tourists come to our country to see the UNESCO World Heritage Sites, get acquainted with the Ukrainian culture and traditions, to feel the incredible national flavor. But today, even under favorable socio-economic and socio-political conditions, the development of cultural tourism and tourism for enlightenment is slow, due to many reasons, and this is a rather big problem. One of the factors that inhibit this process is the lack of qualified staff and low level of services provided. The current situation actualizes the problem of effective training and professional development of specialists capable of providing various types of excursion and tourist services at a high cultural level and with significant economic effect. 
Formulation of the problem. At the moment, despite the fact that there is a large amount of scientific work on the modern problems of professional training and retraining of guides, the ways that provide such level of professional and culturological competence of guides that would enable them to compete successfully in international labor markets remain unclear. Therefore, the problem of finding methods, means and forms of improving modern cultural training and retraining of specialists of tourist support (guides) to work with tourists is currently relevant in our country and abroad.

Analysis of recent research and publications. The problem of the culturological approach in education in its various aspects has been addressed by many domestic and foreign scholars. Modern works in this field are devoted to the development of ideas of the school of cultural and historical psychology (L. Vygotsky, A. Luria and others). Concepts of dialogue of cultures were considered by M. Bakhtin, B. Gershunsky, L. Litovsky and others. Among the studies concerning the culturological approach to education, one can distinguish the works of such scientists as I. Kolmogorov, V. Krainik, L. Lukianova and others. These researchers have developed the conceptual foundations of the culturological approach, the principles of constructing the educational process in the context of this approach in terms of education in different training profiles. However, as the analysis of the scientific literature on the subject shows, a number of aspects regarding the application of the culturological approach in training of future specialists of tourist support (guides) require more detailed study.

Setting objectives. Given the relevance and identified problems in the sphere of our work, the purpose of the article is to research and apply the culturological approach in modern training of specialists in tourist support (guides).

Presenting main material. The tourist and excursion support professional is a tour guide, who is responsible for accompanying tourists along a certain route, familiarizing them with local natural monuments, outstanding people, as well as cult objects of architecture, fundamental masterpieces of culture and art. A qualified tour guide must have a thorough knowledge of historical material, present interesting and fascinating facts, be able to give the trip the necessary emotion and clearly manage excursionist's attention.

Nowadays, almost all over Europe, the requirements to specialists of tourist support (tour guides) are almost the same: higher education (preferably humanitarian); additional specialty training; knowledge of one or more foreign languages; eloquence and clear diction; sociability, openness, friendliness; creativity and a broad outlook; and most importantly, a high level of professional culture.

If the applicants have decided to choose the profession of guide, at present, practically all over the world it is customary to divide it into two separate specialties, namely: guide is a person who organizes excursions and transfers of travelers, accompanying them on a route, informing about its features and deals with filling in 
relevant documentation; the guide is a specialist responsible for the cultural component of any excursion - usually a full-time employee of a museum, gallery or other similar organization [5].

At the moment, the content of the professional training of specialists is the culture - values and meaningful knowledge, ideas that have been reflected in art, religion, tradition and human experience. However, in the context of the traditional system of education, there is a narrow understanding of the culturological approach reducing it to the cultural aspect, the principle of cultural-centricity, which indicates the lack of its methodological justifications and incomplete use of opportunities in this field.

In pedagogical works, enquiries of applied cultural studies, the need for a holistic understanding of the culturological approach in pedagogy is emphasized, when the purpose of education, as a «sphere producing human souls», is the process of human development [1].

Most researchers working on the culturological approach to education see it as their goal in overcoming dehumanizing phenomena in society. The dictionary defines the culturological approach to education as viewing it «through the lens of the concept of culture, i.e. looking at education as a cultural process, carried out in an appropriate cultural educational environment, while all components of the process are filled with human meanings and serve a person who freely expresses his or her individuality, ability to cultural self-development and self-realization in the world of cultural values» [6].

Researchers working on the issue of culturological approach in education, offer the following principles of its construction:

1) creation of educational environment as a cultural, dialogical relations between units of educational material;

2) formation through entering into the culture of personality, as a theoretical and practical subject;

3) emotional saturation of the educational environment;

4) the purpose of the culturological approach is to educate a person with a formed system of values, who builds relations with the world on the basis of this system and is competent in the normative area of their professional sphere;

5) the study of the relationship between culture (and language as its constituent) and consciousness (inner world) of a person, as a carrier of this culture [2].

It is very important that the material of all the subjects taught during the preparation of tour guides be filled with culturological content. Teachers need not only to convey to the students a set of scientific facts and patterns, but also to show their personal and emotional attitude to the material being taught; to specific scientific and historical figures and facts, to show the inseparable connection of certain events with the cultural and historical context. The point is that the idea of its fundamentalization the depth and breadth of philosophical, cultural, general and special knowledge should be the foundations for professional training of a tourist support specialist (guide). 
Fundamentalization frees students from being overloaded by educational information. Teaching should be designed in such a way that even highly specialized educational information would be perceived as an integral component of cultural life, which has its legitimate time and place, so that the mastered fragment of scientific knowledge is interwoven into the cultural fabric of the life of the listener and create the conditions for identification and the realization of personal meanings.

A very important condition for implementation of a culturological approach to professional training of guides is their spiritual and moral development. The spiritual potential of a specialist is determined by the degree of their involvement not only in world culture, but also in national cultural traditions. Until recently, ethnic traditions were considered a nearly forbidden topic in our country. Personality was identified within the society, outside the ethnic group. Today, when different national cultural traditions enter the dialogue, their interaction and enrichment occur, this process creates favorable opportunities for the guide of the processes to comprehend internationalization of social life, formation and functioning of human culture [4].

One of the key points in the implementation of the culturological approach is the need to ensure cultural identification of the future guides.

Cultural identification is seen as an awareness of individual's belonging to a particular culture, of accepting one's values as their own, of choosing and pursuing one's cultural lifestyle and behavior. It is an educational process, the essence of which is to establish a similarity between themselves and their native people, valuing human and national culture, the desire to pursue professional activity in the forms of cultural being of the native people and dialogical communication with other peoples and cultures. Cultural identification cannot be imposed from the outside. It is conditioned internally, has a subjective nature and is a product of the development of national identity of the individual [3].

The future specialists of tourist support (guide) acquire cultural identity as they enter the national culture and develop as a citizen, a person of culture and a subject of cultural types of professional activity.

Today, in Ukraine, as a multinational state, the issue of national values is rather elusive and delicate, requiring many factors of interethnic interaction to be taken into account. There are no good or bad cultures. The only acceptable form of their coexistence and interaction is dialogue, which is one of the tools of culturological approach.

Unfortunately, the professional activity of the guide is strictly determined and passive to some extent. This passivity has no place in development of cultural values: there is no culture without free activity. It can be acquired provided the tourist support specialist has freedom of choice and an independent professional development 
strategy. Therefore, the system of training of guides should provide a differentiated system of special courses, special seminars, special workshops, electives on various problems of humanitarian knowledge: philosophy and culture, culture of selfrealization, culture of international communication and so on.

It should be noted that the culturological approach to professional activity of a tourist support specialist (guide) has a number of nuances, which express the dialectic of this concept. First, professional activity itself is an integral part, phenomenon of culture. Therefore, its development can be ensured only in socio-cultural historical framework. At the same time, the professional activity of a guide is not only a cultural development, but also a process of transmission, transfer of cultural patterns of life and behavior. At the same time, it is very important that this process is carried out in the context of culture, so that its results are not utilitarian knowledge, habits and skills, but also the learned values of culture [4].

As prospects for the implementation of a culturological approach in the professional training of future tourist support specialists (guides), we are considering the formation of a new type of education system - multicultural education. It provides an opportunity to profoundly study and understand diversity of peoples worldwide, to see commonalities in this diversity. Students need to be aware that there are many values in the world, that some of these values are different from their own, that any values lie in the traditions of a particular people and are a natural product of their experience and historical development. It is only through the polylogue with other cultures that one can attain a certain level of self-knowledge, since in the polylogic encounter of many cultures, each of them maintains its unity and open integrity, while enriching the others.

Clearly, in a rather multinational Ukrainian society, multicultural education becomes an integral part of the guide's professional activity, a source and means of their development. It includes cultural, ethnohistorical knowledge, understanding of the importance of cultural pluralism, the ability to distinguish and introduce ideas that reflect the cultural diversity of the world to the content of education.

Conclusion. The existing technocratic educational paradigm puts the future tourist support specialist (guide) outside the context of world and national culture. The need to change the paradigm of rational knowledge to the paradigm of the multicultural understanding becomes obvious.

At present, the student's personality and culture come into the focus, while knowledge and skills students are mastering transform and instead of being the objective of training become the means of professional development and selfimprovement. The criterion of knowledge as a phenomenon of culture becomes not so much its correspondence to reality, but the harmonization of a given form of knowledge with the general values pertinent to a particular culture. 
Culturological approach as a methodology of a new type of education, which suggests looking at the pedagogical process through the prism of culture, that is, its perception as a cultural process, carried out in conformity of cultural and educational environments. All components of this process are filled with human meanings and serve individuals who can freely demonstrate individuality, develop intercultural competence and define themselves in the world of cultural values.

When solving the tasks of professional development of future tourist support specialists (guides) on the basis of culturological approach, it is necessary to build professional training as a process of acquiring the ability to live in compliance with demands of a particular culture by individuals, reproduction of its achievements and creation of new spiritual and tangible assets.

\section{REFERENCES}

1. Gershunsky, B. (2014). Education Philosophy for the 21st Century: self study guide. Moscow : Science and Life.

2. Kolmogorova, I. (2008). «Culturological approach to the formation pedagogical culture of a specialist», News of the Ural State University, Vol. 60, pp. $163-167$.

3. Kraynik, V. (2005). Culture of students' educational activity: a training manual. Barnaul: BSPU.

4. Lukianova, L. (2008). Education in Tourism. Kyiv: Vy'sha shkola.

5. Schuka, G. (2013). The system of vocational education in the field of tourism in the Russian Federation, Ukraine and the Republic of Belarus: monograph. Luhansk: DZ «LNU imeni Tarasa Shevchenko».

6. World of dictionaries: Cultural approach. Retrieved from: http://mirslovarei.com/ content_eco/kulturologicheskij-podxod-32415.html 